\title{
MODEL PEMBIAYAAN BAGI HASIL DAN INOVASI BISNIS TERHADAP PERTUMBUHAN PELANGGAN DAN KINERJA USAHA TANI TEBU MIKRO DAN KECIL DI KABUPATEN BONDOWOSO
}

\author{
Mohamad Dimyati, M. Fathorrazi, Andriana \\ Fakultas Ekonomi Universitas Jember \\ dim_ekounej@yaboo.co.id
}

\begin{abstract}
The purpose of this study was to determine and analize the influences of profit sharing financing system to the business innovation, and to perform business, assets to the business innovation, and to perform business innovation to customer growth, and to business performance, customer growth to the performances of business. The type of this research is exploratory research study. The population was Sugarcane Farmings in Kab.Bondowoso. The amount of Small and Micro Sugarcane Farmings who use financing funds are 50 units. The sampling technique conducted with a purposive sampling technique. The research showed that Financing have a significant effect on business innovation. Furthermore, profit sharing financing also bave a significant effect on the performance of sugar cane farming. The asset of sugar cane farming has an effect on business innovation, and affects the performance of sugar cane farming. Business innovation affect on customer growth, and performance sugar cane farming. Customer growth affects the performance sugar cane farming.
\end{abstract}

Keyword: Profit Sharing Financing, Business Inovation, Customer Growth, Performance

\begin{abstract}
Abstrak
Tujuan dari penelitian ini adalah untuk mengetahui dan menganalisis pengarub sistem bagi hasil pembiayaan terbadap inovasi bisnis, dan kinerja bisnis, aset terhadap inovasi bisnis, dan kinerja, inovasi bisnis terhadap pertumbuban pelanggan, dan kinerja bisnis, pertumbuban customer terbadap kinerja bisnis. Jenis penelitian ini adalah penelitian eksploratif. Populasi penelitian ini adalah Usaha tani tebu di Kabupaten Bondowoso. Sampel penelitian adalah usaha tani tebu di Kab. Bondowoso. Jumlab usaba tani tebu mikro dan kecil yang menggunakan dana pinjaman 50 unit. Teknik pengambilan sampel penelitian dilakukan dengan teknik purposive sampel. Hasil penelitian menunjukkan bahwa Pembiayaan berpengarub signifikan terhadap inovasi bisnis, dan kinerja usaha tani tebu. Asset usaba tani tebu berpengarub signifikan terhadap inovasi bisnis dan kinerja usaha tani tebu. Inovasi bisnis berpengarub signifikan terbadappertumbuhan pelanggan dan kinerja usaba tani tebu. Pertumbuban pelanggan juga berpengarub signifikan terbadap kinerja usaba tani tebu
\end{abstract}

Kata Kunci: Pembiayaan bagi Hasil, Inovasi bisnis, Pertumbuhan Pelanggan, Kinerja 


\section{Pendahuluan}

Salah satu tantangan paling mendasar dalam pembangunan nasional sekarang ini adalah bagaimana keluar dari jebakan krisis moneter dan ekonomi serta membangun bangsa ini untuk mampu bersaing pada era perdagangan bebas millennium 3. Jika tantangan tersebut dapat diatasi secara cerdas dan tetap, maka cita-cita menjadikan Indonesia sebagai bangsa yang maju dan mandiri dengan masyarakatnya yang makmur dan berkeadilan akhir pembangunan jangka panjang II (PJP II) adalah suatu keniscayaan.

Untuk bisa menjawab tantangan tersebut diperlukan penciptaan sumber-sumber pertumbuhan ekonomi baru dan secara simultan merevitalisasi sumber-sumber pertumbuhan yang sudah kita miliki sejak PJP I. selain itu barang dan jasa yang kita hasilkan melalui berbagai macam kegiatan ekonomi (pembangunan) harus memiliki produktifitas dan daya saing yang tinggi sehingga mampu bersaing pada pasar domestic maupun global. Salah satu sumber pertumbuhan ekonomi yang perlu dioptimalkan adalah bidang agroindustri. Memasuki era PJP II, sub sector Agroindustri merupakan salah satu prioritas yang harus dikembangkan dalam pembangunan nasional. Pengembangan Agroindustri dimaksudkan untuk mendapatkan seoptimal mungkin peluang potensi sector pertanian dan sector-sektor lainnya yang terkait dalam rangka meningkatkan nilai tambah produk nasional serta memperkokoh sturktur perekonomian kita.

Dalam rangka meningkatkan nilai tambah produk nasional dan memperkokoh struktur perekonomian kita maka pengembangan ekonomi harus dilaksanakan sesuai dengan kompetensi dan produk unggulan di setiap daerah, terutama pertanian dalam arti luas. Pengembangan produk unggulan daerah yang memanfaatkan produk pertanian dalam arti luas yang disesuaikan dengan kompetensi daerah akan mendorong tumbuhnya agroindustri. Pengembangan produk unggulan daerah yang sebagaian besar adalah produk pertanian akan semakin dikembangkan dan dipercepat.

Kabupaten Bondowoso merupakan salah satu daerah yang perekonomiannya mengandalkan pada sector perkebunan, pertanian, dan peternakan. Salah satu jenis komoditi dari sub sector per- 
kebunan yang mendominasi sekitar 38,28 \% adalah tebu. Selain memiliki keunggulan kompetitif juga mempunyai nilai ekonomi cukup tinggi yang dapat meningkatkan perolehan Pendapatan Asli daerah (PAD).

Perkembangan volume produksi tebu kebupaten bondowoso selama kurun waktu lima tahun terakhir terlihat mengalami peningkatan yang cukup pesat. Volume produksi tebu Kabupaten Bondowoso tahun 2006 sebesar 29,476 ton pertahun.. Namum pada tahun 2009 mengalami penurunan menjadi 36.752 ton. Para petani tebu yang ada di kabupaten Bondowoso mayoritas merupakan petani tebu dalam skala usaha mikro dan kecil yang banyak mengalami permasalahan dalam usaha lebih meningkatkan meningkatkan lagi volume produksi tebu di Kabupaten Bandowoso. Permasalahan yang dialami oleh peteni tebu mikro dan kecil tersebut antaranya adalah masalah pembiyaan dan inovasi produk yang telah dilakukan. Oleh karena itu diperlukan model pembiayaan dan inovasi produk bagi usaha tani tebu mikro dan kecil di kabupaten Bondowoso.

Dana pembiayaan bagi petani tebu sangat di butuhkan untuk peningkatan kualitas suatu produk, sehingga dengan meningkatnya kualitas produk, pertumbuhan pelanggan akan semakin pesat dan omset penjualan akan tinggi sehingga menghasilkan laba/ keuntungan yang besar juga. Oleh karena itu semakin besar dana yang dimiliki oleh petani tebu maka kemungkinan memperoleh laba/keuntungan akan semakin besar juga. Perusahaaan yang didasarkan pada kegiatan inovasi akan lebih cepat tumbuh dan lebih stabil. Oleh sebab itu sebaiknya petani tebu melakukan investasi untuk kegiatan inovasi yang dapat berkibat terhadap peningkatan kualitas suatu produk, sehingga pertumbuhan pelanggan akan semakin pesat dan omset penjualan akan tinggi pada akhirnya menghasilkan laba tinggi.

Perusahaaan yang aktif melakukan inovasi akan lebih cepat tumbuh dan lebih stabil. Oleh sebab itu sebaiknya perusahaan melakukan investasi untuk kegiatan inovasi. Namun inovasi bisnis akan bisa dilakukan jika pengusaha UMKM mampu mengelola asset dengan baik dan benar. Semakin baik manajemen mengelola asset perusahaan semakin baik pula inovasi bisnis UMKM. Semakin 
manajemen mengelola asset perusahaan semakin baik laba yang diperoleh berarti semakin besar pula kinerja perusahaan. Oleh karena itu kinerja perusahaan sangat dipengaruhi oleh baik tidaknya pengelolaan asset perusahaan.

Inovasi sebagian besar dipandang pada tingkat produk atau proses dimana inovasi produk tersebut memuaskan kebutuhan konsumen dan inovasi proses meningkatkan efektifitas dan efisiensi. Inovasi bisnis yang terdiri dari inovasi produk, proses dan sistem organisasi diperlukan guna memenuhi kebutuhan dan kepuasan pelanggan. Inovasi bisnis merupakan strategi dalam rangka mempertahankan pelanggan yang sudah ada sekaligus menarik pembeli/ pelanggan baru. Dengan semakin baik manajemen UMKM melakukan inovasi bisnis maka diharapkan pelanggan UMKM akan semakin tumbuh dan bertambah.

Untuk membedakan secara mudah usaha skala kecilmenengah dengan usaha skala besar adalah dari aspek legalitas. Menurut Undang-Undang Republik Indonesia Nomor 20 Tahun 2008 Tentang Usaha Mikro dan Kecil adalah sebagai berikut:

1. Usaha Mikro adalah usaha produktif milik orang perorangan dan atau badan usaha perorangan yang memenuhi criteria Usaha Mikro sebagaimana diatur dalam Undang-Undang ini;

2. Usaha Kecil adalah usaha ekonomi produktif yang berdiri sendiri, yang dilakukan oleh orang perorangan atau badan usaha yang bukan merupakan anak perusahaan atau bukan cabang perusahaan yang dimiliki, dikuasai, atau menjadi bagian baik langsung maupun tidak langsung dari usaha menengah atau usaha besar yang memnuhi kriteria usaha kecil sebagaimana dimaksud dalam undang-undang ini.

Sebagian besar usaha bisnis di Indonesia berbentuk UMKM yang memiliki karakteristik tersendiri sesuai dengan realitas perekonomian Indonesia. Usaha yang mereka jalankan mampu berdiri di atas kaki sendiri dan bersifat mandiri tanpa memiliki grup atau di bawah grup perusahaan lain. Kebanyakan produksinya bukan berupa jasa tetapi barang menggunakan teknologi yang relatif rendah. Orientasinya terfokus pada pasar lokal sehingga lokasinya pun berada di pedesaan atau pinggiran kota. Modal mereka juga 
terbatas dan yang pasti usahanya pun sangat susah mendapatkan pinjaman kredit atau pembiayaan dari bank, dengan kata lain termasuk kategori unbankable.

Inovasi sebagian besar dipandang pada tingkat produk atau proses dimana inovasi produk tersebut memuaskan kebutuhan konsumen dan inovasi proses meningkatkan efisiensi dan efektifitas. Peningkatan efisiensi dan efektifitas, manajemen UMKM akan lebih mampu meningkatkan kinerja UMKM. Perusahaan yang mampu meningkatkan inovasi produknya berimplikasi meningkatkan kinerja keuangan perusahaan.

Pelanggan sebenarnya merupakan asset terbesar bagi perusahaan, karena tanpa mereka perusahaan tidak akan ada. Kelangsungan suatu bisnis mutlak tergantung dari ada tidaknya perhatian yang besar terhadap kebutuhan pelanggan. Semakin banyak dan semakin loyal pelanggan terhadap perusahaan, maka semakin kuat kemungkinan bisnis /usaha meraih sukses. Oleh karena itu, semakin banyak pelanggan maka omset penjualan akan semakin tinggi dan secara otomatis jika penjualan meningkat, laba/keuntungan akan meningkat juga. Perhatian terhadap pengembangan dan perkembangan usaha kecil dan menengah akhir-akhir ini semakin meningkat.Hal ini terjadi karena pertama, adanya perhatian yang cukup besar untuk memberikan peluang bagi usaha skala besar untuk berperan, sebaliknya kurang adanya perhatian yang cukup terhadap usaha skala kecil/menengah. Kedua, adanya pendapat bahwa masa depan dunia akan dikuasai oleh usaha skala kecil dan menengah. Ketiga, adanya kecendrungan berbagai negara untuk memfokuskan perhatiannya pada pembinaan usaha skala kecil-menengah.Keempat, alasan ketidakpuasan terhadap industri besar yang nyata tidak menghasilkan kemandirian, meskipun telah didukung dengan berbagai macam proteksi.

Perkembangan lingkungan bisnis terjadi secara dinamis mempengaruhi setiap perusahaan. Perubahan teknologi dan variasi produk yang cepat mempenga-ruhi perkembangan semua industri. Era perdagangan bebas dunia akan mereduksi bea masuk antar negara. Tantangan yang akan dihadapi adalah terbukanya batas wilayah dan batas persaingan, sehingga kegiatan ekonomi 
bergantung pada persaingan global yang bebas terbuka, dimana hanya pelaku bisnis yang kuat yang akan menang dan tetap bertahan. Kemajuan teknologi yang cepat dan tingginya tingkat persaingan menuntut perusahaan untuk terus menerus melakukan inovasi produk yang pada akhirnya akan meningkatkan kinerja bisnis organisasi.

Kinerja bisnis menjadi kunci pokok untuk tetap bertahan dalam era global. Banyak faktor yang menentukan kinerja bisnis suatu organisasi, salah satu diantaranya adalah inovasi. Kemajuan teknologi yang cepat dan tingginya tingkat persaingan menuntut per-usahaan untuk terus menerus melakukan inovasi yang pada akhirnya akan meningkatkan kinerja bisnis organisasi.

Inovasi merupakan komersialisasi awal penemuan dengan menghasilkan dan menjual suatu produk, jasa, atau proses baru. Inovasi pada dasarnya mengubah ide menjadi keuntungan (Pearce and Robinson, 2013). Inovasi merupakan proses teknologis, manajerial dan sosial, dimana gagasan atau konsep baru pertama kali diperkenalkan untuk dipraktekkan dalam suatu kultur (Quinn, Baruch \& Zien, 1996). Tujuan utama proses inovasi adalah memberikan dan menyalurkan nilai pelanggan yang lebih baik. Kemampuan inovasi merupakan kemampuan organisasi untuk mengadopsi atau mengimplementasikan gagasan baru, proses dan produk baru (Hurley \& Hult, 1998). Jenis inovasi yang banyak digunakan penelitiian dalah inovasi produk dan inovasi proses.

Model bisnis suatu pemahaman yang jelas mengenai bagaimana perusahaan akan menghasilkan laba dan tindakan strategis yang harus dilaksanakannya untuk sukses dalam jangka panjang (Pearce and Robinson, 2013). Mengacu pada pengertian inovasi dan model bisnis seperti dikemukakan oleh para ahli tersebut, maka dapat disimpulkan bahwa inovasi bisnis merupakan suatu pemahaman yang jelas menganai proses teknologis, manajerial dan sosial, dimana gagasan atau konsep baru pertama kali diperkenalkan untuk dipraktekkan dalam suatu kultur usaha bisnis.

Inovasi produk didefinisikan sebagai produk atau jasa baru yang diperkenalkan ke pasar untuk memenuhi kebutuhan pasar (Damanpour, 1991). Inovasi proses menggambarkan perubahan 
dalam cara organisasi memproduksi produk dan jasa akhir dari suatu perusahaan (Cooper, 1998). Inovasi perusahaan baik inovasi proses dan inovasi produk akan meningkatkan kualitas produk.

Hasil penelitian Kusumo (2006) menemukan bahwa orientasi teknologi yang merupakan bagian dari dilakukan oleh industri batikdi Kotadan Kabupaten Pekalongan merupakan cara yang digunakan oleh perusahaan untuk beradaptasi, baik pada alatnya atau proses pemahaman terhadap alat-alat yang baru yang dapat membantu perusahaan untuk menciptakan produk yang inovatif.

Dengan optimisme pertumbuhan volume produksi tebu di Kabupaten Bondowoso, kekurangan permodalan serta perlunya inovasi proses, produk dan system organisasi maka mendorong peneliti untuk melakukan penelitian ilmiah dengan judul : "Model Pembiayaan Bagi Hasil dan Inovasi Bisnis Terhadap Pertumbuhan Pelanggan dan Kinerja Usaha Tani Tebu Mikro dan Kecil di Kabupaten Bondowoso".

\section{Permasalahan}

Terdapat permasalahan yang dijabarkan dalam tujuh hipotesis yang diajukan dalam penelitian terhadap Usaha Tani Tebu Mikro dan Kecil di Kabupaten Bondowoso. Tujuh hipotesis penelitian tersebut adalah sebagai berikut:1) apakah pembiayaan dengan sistem bagi hasil berpengaruh terhadap inovasi bisnis;2) apakah pembiayaan dengan sistem bagi hasil berpengaruh terhadap kinerja; 3) apakah aset usaha berpengaruh terhadap inovasi bisnis; 4) apakah aset usaha berpengaruh terhadap kinerja; 5) apakah inovasi bisnis berpengaruh terhadap pertumbuhan pelanggan; 6)apakah inovasi bisnis berpengaruh terhadap kinerja usaha; 7) apakah pertumbuhan pelanggan berpengaruh terhadap kinerja usaha;

\section{Tujuan Penelitian}

Tujuan penelitian yang dilakukan terhadai Usaha Tani Tebu Mikro dan Kecil di Kabupaten Bondowoso ini adalah untuk mengetahui dan menganalisis pengaruh: 1) pembiayaan sistem bagi hasil terhadap inovasi bisnis; 2) pembiayaan dengan sistem bagi hasil terhadap kinerja Usaha; 3) aset terhadap inovasi bisnis; 4) aset 
terhadap kinerja usaha; 5) inovasi bisnis terhadap pertumbuhan pelanggan; 6) inovasi bisnis terhadap kinerja usaha; 7) pertumbuhan pelanggan terhadap kinerja usaha;

\section{Metode Penelitian}

Desain penelitian ini menggunakan jenis penelitian exploratory research karena tujuan penelitian adalah untuk menjelaskan hubungan-hubungan dari variable-variabel melalui pengujian hipotesis yang telah dirumuskan. Sedangkan metode pengumpulan data dilakukan melalui survey. Dalam penelitian ini dilakukan uji statistik untuk menjawab rumusan masalah, dan untuk menyempurnakan penelitin ini juga digunakan metode kualitatif yang bertujuan untuk mengetahui dan menganalisis manfaat dan kendala yang dihadapi usaha tani tebu terkait dengan pembiayaan system bagi hasil.

Penelitian ini menggunakan data primer dan sekunder. Populasi penelitian ini adalah Usaha tani tebu di Kabupaten Bondowoso. Sampel penelitian adalah usaha tani tebu di Kabupaten Bondowoso yang menggunakan dana pinjaman. Jumlah usaha tani tebu mikro dan kecil di Kabupaten Bondowoso yang menggunakan dana pinjaman 50 unit. Teknik pengambilan sampel penelitian dilakukan dengan teknik purposive sampel dengan kriteria sebagai berikut:

a. Tidak menjadikan semua usaha tani tebu yang menggunakan dana pembiayaan sebagai sampel melainkan pemilihannya dilihat dari usaha tani tebu yang tidak mengalami keterlambatan dalam pembayaran.

b. Dari setiap jenis usaha tani tebu yang menggunakan dana pembiayaan diambil satu usaha tani tebu untuk dijadikan sampel.

c. usaha tani tebu yang mendapatkan dana pembiayaan adalah mereka yang kekurangan modal untuk usaha dan dijadikan sebagai sample. 
Variabel-variabel yang akan dianalisis dalam penelitian ini dikelompokkan sebagai berikut:

1. Pembiayaan sistem bagi hasil sebagai variabel eksogen yang independen yang pertama (X1). Variabel ini diukur dengan jumlah dana syirkah.

2. Asset usaha mikro, kecil dan menengah sebagai variabel eksogen yang independen yang kedua (X2). Variabel ini diukur dengan jumlah asset(aktiva).

3. Inovasi bisnis sebagai variabel endogen yang independen (intervening) yang pertama (Y1). Variabel ini diukur dengan perbaikan dalam produk, proses dan sistem organisasi.

4. Pertumbuhan pelanggan sebagai variabel endogen yang independen (intervening) yang kedua (Y2). Variabel ini diukur dengan rasio pertumbuhan pelanggan.

5. Kinerja UMKM sebagai variabel endogen yang dependen yang ketiga (Y3). Variabel ini diukur dengan return on average assets (ROAA), return on average shareholders equity (ROAE).

Teknik analisis data menggunakan analisis kuantitatif dan kualitatif. analisis kuantitatif yang digunakan terdiri dari analisis deskriptif untuk melihat gambaran karakteristik populasi dan analisis jalur. Analisis jalur digunakan untuk pengujian hipotesis dengan menggunakan Partial Least Squares (PLS). Model formal PLS mendefinisikan variabel bentukan adalah linier agregat dari indikatorindikatornya. Estimasi terbobot yang dipergunakan untuk menciptakan komponen skor variabel didapat berdasarkan spesifikasi terhadap inner model dan outermodel. Analisis kualitatif ini digunakan untuk mendukung analisis masalah-masalah dalam studi ini yang kurang mampu dijawab dan dianalisis dengan analisis kuantitatif. Pengujian hipotesis dilakukan berdasarkan model seperti Gambar dibawah ini. 


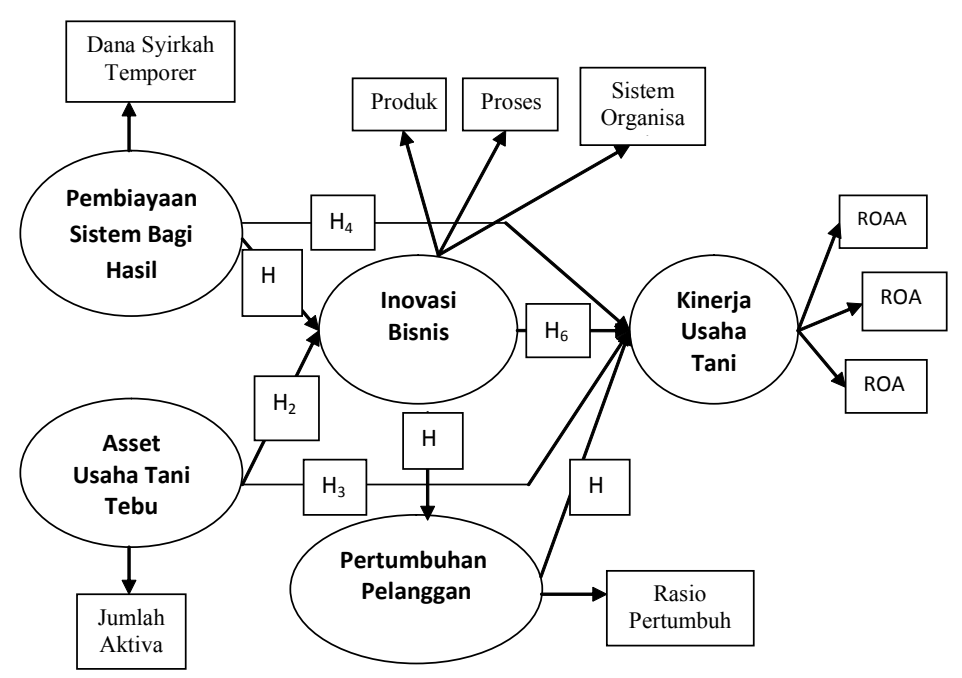

Gambar 1: Diagram Jalur Lengkap Dengan Outer Model

\section{Analisis Data}

Penelitian ini menggunakan model persamaan struktural (Structural Equation Model/SEM) dengan menggunakan Partial Least Square (PLS) Model formal PLS mendefinisikan variabel bentukan adalah linear agregat dari indikator-indikator yang digunakan. Estimasi yang digunakan adalah untuk menciptakan komponen skor dari variabe yang spesifik terhadap inner model dan outer model.

Pengujian hipotesis dilakukan dengan melakukan langkahlangkah berikut. Pertama, untuk outer modeldengan indikator reflektif dievaluasi berdasarkan pada konten substantifnya, yaitu dengan membandingkan besarnya bobot relatif dan melihat signifikansi bobot tersebut. Kedua, inner model dievaluasi dengan melihat persentase varian yang dijelaskan yaitu dengan melihat nilai $\mathrm{R}^{2}$ untuk konstruk endogen dan juga melihat besarnya koefisien jalur struktural.

Convergen validity dari measurement modeldengan indikator yang diteapkandapat dilihat dari nilai korelasi antara score item/ indikator dengan score konstruknya. Suatu indikator dikatakan reliabel jika memiliki nilai diatas 0.50 . 
Tabel 1: Outer Loadings

\begin{tabular}{lcccc}
\hline & $\begin{array}{c}\text { Original } \\
\text { Sample (O) }\end{array}$ & $\begin{array}{c}\text { Sample } \\
\text { Mean (M) }\end{array}$ & $\begin{array}{c}\text { Standard } \\
\text { Deviation } \\
\text { (STDEV) }\end{array}$ & $\begin{array}{c}\text { Standard } \\
\text { Error } \\
\text { (STERR) }\end{array}$ \\
\hline $\begin{array}{l}\text { DANASYIRKAH <- } \\
\text { Pembiayaan Sistem Bagi }\end{array}$ & 1,000000 & 1,000000 & 0,000000 & \\
$\begin{array}{l}\text { Hasil } \\
\text { JUMLAHAKTIVA <- Asset } \\
\text { Usaha Tani Tebu }\end{array}$ & 1,000000 & 1,000000 & 0,000000 & \\
$\begin{array}{l}\text { ORGANISASI <- Inovasi } \\
\text { Bisnis }\end{array}$ & 0,770565 & 0,744591 & 0,168518 & 0,168518 \\
$\begin{array}{l}\text { PERTUMBUHAN <- } \\
\text { Pertumbuhan } \\
\text { Pelanggan }\end{array}$ & 1,000000 & 1,000000 & 0,000000 & \\
$\begin{array}{l}\text { PRODUK <- Inovasi } \\
\text { Bisnis }\end{array}$ & 0,511655 & $-0,380026$ & 0,262508 & 0,262508 \\
$\begin{array}{l}\text { PROSES <- Inovasi } \\
\text { Bisnis }\end{array}$ & 0,836783 & 0,788724 & 0,129830 & 0,129830 \\
$\begin{array}{l}\text { ROA <- Kinerja Usaha } \\
\text { Tani Tebu } \\
\text { ROE <- Kinerja Usaha }\end{array}$ & 0,893594 & 0,547529 & 0,555991 & 0,555991 \\
Tani Tebu & 0,598479 & 0,523404 & 0,492693 & 0,492693 \\
\hline
\end{tabular}

Sumber : Output PLS diolah 2013

Berdasarkan pada outer loadings diatas maka dapat dikatakan bahwa semua indikator memiliki nilai yang signifikan dan memenuhi convergent validity karena semua fakctor loadings memiliki nilai diatas 0.50 .

Discriminant validity dari indikator penelitian ini dapat dilihat pada cross loading antara indikator dnegan konstruknya pada Tabel 2 dan 3.

Tabel 2: Cross Loading

\begin{tabular}{lllll}
\hline & $\begin{array}{l}\text { Asset Usaha } \\
\text { Tani Tebu }\end{array}$ & $\begin{array}{l}\text { Inovasi } \\
\text { Bisnis }\end{array}$ & $\begin{array}{l}\text { Kinerja Usaha } \\
\text { Tani Tebu }\end{array}$ & $\begin{array}{l}\text { Pembiayaan } \\
\text { Sistem Bagi Hasil }\end{array}$ \\
\hline DANA SYIRKAH & 0,937386 & $-0,410584$ & $-0,075443$ & $\mathbf{1 , 0 0 0 0 0 0}$ \\
JUMLAH & $\mathbf{1 , 0 0 0 0 0 0}$ & $-0,352882$ & $-0,227839$ & 0,937386 \\
AKTIVA & & & & \\
ORGANISASI & $-0,321344$ & $\mathbf{0 , 7 7 0 5 6 5}$ & $-0,031099$ & $-0,397647$ \\
PERTUMBUHAN & $-0,275686$ & 0,224844 & $-0,138481$ & $-0,220158$ \\
PRODUK & 0,078658 & $\mathbf{0 , 4 1 1 6 5 5}$ & 0,105158 & 0,085463 \\
PROSES & $-0,260354$ & $\mathbf{0 , 8 3 6 7 8 3}$ & $-0,205314$ & $-0,283405$ \\
ROA & $-0,326482$ & $-0,122832$ & $\mathbf{0 , 8 9 3 5 9 4}$ & $-0,230694$ \\
ROE & 0,160302 & $-0,101056$ & $\mathbf{0 , 3 9 8 4 7 9}$ & 0,303562 \\
\hline
\end{tabular}

Sumber: output PLS diolah 2013

Dari Tabel 2 dan 3, tersebut terlihat bahwa kontruk dan masingmasing indikatornya memiliki nilai yang lebih tinggi jika dibandingkan konstruk lain dan nindikator lainnya. Hal ini menunjukkan bahwa 
konstruk laten mampu memprediksi indikator pada blok mereka lebih baik jika dibandingkan dnegan indikator di blok lainnya.

Tabel 3: Cross Loading (lanjutan)

\begin{tabular}{lc}
\hline & Pertumbuhan Pelanggan \\
\hline DANA SYIRKAH & $-0,220158$ \\
JUMLAH AKTIVA & $-0,275686$ \\
ORGANISASI & 0,036411 \\
PERTUMBUHAN & $\mathbf{1 , 0 0 0 0 0 0}$ \\
PRODUK & 0,127097 \\
PROSES & 0,327351 \\
ROA & $-0,165047$ \\
ROE & 0,029208 \\
\hline
\end{tabular}

Sumber: output PLS diolah 2013

Disamping uji validitas konstruk, dilakukan juga uji reliabilitas konstruk yang diukur dengan dua kriteria yaitu composite reliability dan cronbach alpha dari indikator yang mengukur konstruk. Konstruk dinyatakan reliabel jika memiliki nilai composite reliability maupun cronbach alpha diatas 0,70. Tabel 4 menunjukkan hasil dari composite reliability dari konstruk penelitian semuanya menunjukkan di atas 0,70.

Tabel 4: Composite Reliability

\begin{tabular}{lc}
\hline & Composite Reliability \\
\hline Asset Usaha Tani Tebu & 1,000000 \\
Inovasi Bisnis & 0,481983 \\
Kinerja Usaha Tani Tebu & 0,615545 \\
Pembiayaan Sistem Bagi Hasil & 1,000000 \\
Pertumbuhan Pelanggan & 1,000000 \\
\hline
\end{tabular}

Sumber : output PLS diolah 2013

Tabel 5 menunjukkan hasil dari cronbach alpha dari konstruk penelitian semuanya menunjukkan di atas 0,70. Dengan demikian dapat disimpulkan bahwa semua konstruk penelitian memiliki reliabilitas yang baik. 
Tabel 5: Cronbach Alpha

\begin{tabular}{ll}
\hline & Cronbachs Alpha \\
\hline Asset Usaha Tani Tebu & 0,847000 \\
Inovasi Bisnis & 0,731627 \\
Kinerja Usaha Tani Tebu & 0,817790 \\
Pembiayaan Sistem Bagi Hasil & 0,717059 \\
Pertumbuhan Pelanggan & 0,856340 \\
\hline
\end{tabular}

Sumber : output PLS diolah 2013

Pengujian terhadap model strukturak dalam penelitian ini dilakukan dengan melihat nilai R-square yang merupakan nilai uji goodness-fit model. Adapun dalam penelitian ini diperoleh nilai Rsquare seperti disajikan dalam Tabel 6.

Tabel 6: R-square

\begin{tabular}{lc}
\hline & R Square \\
\hline Asset Usaha Tani Tebu & 0,745082 \\
Inovasi Bisnis & 0,877017 \\
Kinerja Usaha Tani Tebu & 0,789249 \\
Pembiayaan Sistem Bagi Hasil & 0,845297 \\
Pertumbuhan Pelanggan & 0,750555 \\
\hline
\end{tabular}

Sumber : output PLS diolah 2013

Uji yang kedua yaitu melihat signifikansi variabel konstruk yang digunakan dalam penelitian ini dengan melihat nilai koefisien parameter dan nilai signifikansi t statistic yang terdapat pada model Penelitian pada Gambar 2.

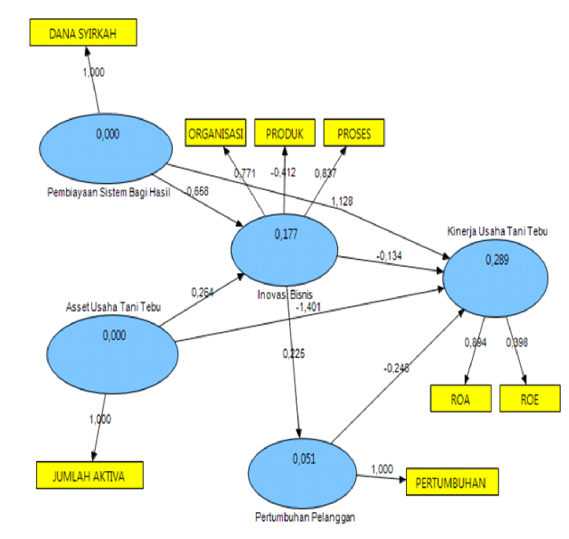

Gambar 2. Model Uji Signifikansi Pengaruh Variabel 
Tabel 7: menunjukkan koefisien jalur dalam model yang digunakan. Hasil yang ditunjukkan yaitu semua konstruk yang digunakan memiliki nilai yang signifikan karena nilai t-hitung lebih besar dari t-tabel (t-tabel signifikansi 5\%=1,68). Adapun koefisien jalur dari semua konstruk yang digunakan dalam penelitian ini memiliki nilai yang positif.

Tabel 7: Path Coefficient (Mean, STDEV, T-Values)

\begin{tabular}{|c|c|c|c|c|c|}
\hline $\begin{array}{l}\text { Sample Mean } \\
\text { (M) }\end{array}$ & $\begin{array}{l}\text { Standard } \\
\text { Deviation }\end{array}$ & Standard & & I Statistic & \\
\hline $\begin{array}{l}\text { Asset Usaha Tani Tebu -> Inovasi } \\
\text { Bisnis }\end{array}$ & 0,263742 & 0,302549 & 0,292161 & 0,008015 & 2,292161 \\
\hline $\begin{array}{l}\text { Asset Usaha Tani Tebu -> Kinerja } \\
\text { Usaha Tani Tebu }\end{array}$ & 1,400508 & 1,063255 & 0,468411 & 0,026536 & 4,468411 \\
\hline $\begin{array}{l}\text { Inovasi Bisnis -> Kinerja Usaha } \\
\text { Tani Tebu }\end{array}$ & 0,133924 & 0,091982 & 0,200987 & 0,015773 & 3,200987 \\
\hline $\begin{array}{l}\text { Inovasi Bisnis -> Pertumbuhan } \\
\text { Pelanggan }\end{array}$ & 0,224844 & 0,218946 & 0,157487 & 0,016188 & 2,157487 \\
\hline $\begin{array}{l}\text { Pembiayaan Sistem Bagi Hasil -> } \\
\text { Inovasi Bisnis }\end{array}$ & 0,657812 & 0,686055 & 0,299681 & 0,030807 & 4,299681 \\
\hline $\begin{array}{l}\text { Pembiayaan Sistem Bagi Hasil -> } \\
\text { Kinerja Usaha Tani Tebu }\end{array}$ & 1,128209 & 0,937496 & 0,547926 & 0,021869 & 3,547926 \\
\hline $\begin{array}{l}\text { Pertumbuhan Pelanggan -> Kinerja } \\
\text { Usaha Tani Tebu }\end{array}$ & 0,246085 & 0,156118 & 0,216714 & 0,015783 & 3,216714 \\
\hline
\end{tabular}

Sumber : output PLS diolah 2013

\section{Pembahasan}

Pembahasan ini akan menjawab masalah dan tujuan penelitian berdasarkan hasil analisis deskriptif, dan analsis hasil penelitian dengan menggunakan program smartpls. Berdasarkan nilai koefisiensi serta taraf signifikansinya akan dibahas terkait tujuan penelitian ini dilakukan.

\section{Pengarub Pembiayaan Sistem Bagi Hasil Terhadap Inovasi Bisnis}

Pada tabel 7 menunjukkan koefisien jalur dalam model yang digunakan. Penelitian ini menghasilkan temuan bahwa variabel Pembiayaan Sistem bagi hasil berpengaruh secara signifikan terhadap Inovasi Bisnis. Hal ini dilihat dari nilai t-hitung 4,299681 lebih besar dari t-tabel (t-tabel signifikansi 5\%=1,68), dan koefisien jalur memiliki nilai positif.

Hasil penelitian menunjukkan bahwa pembiayaan sistem bagi hasil memiliki pengaruh yang signifikan dengan pola hubungan yang 
positif terhadap inovasi bisnis. Hasil ini dapat menjelaskan bahwa semakin baik sistem bagi hasil yang diterima oleh usaha tani tebu di Bondowoso akan mendorong peningkatan terhadap inovasi bisnis.

Pengaruh Pembiayaan Sistem Hasil Terhadap Kinerja Usaha Tani Tebu

Tabel 7, menunjukkan koefisien jalur dalam model yang digunakan. Penelitian ini menghasilkan temuan bahwa variabel Pembiayaan Sistem bagi hasil berpengaruh secara signifikan terhadap Kinerja Usaha tani tebu. Hal ini dilihat dari nilai t-hitung 3,547926 lebih besar dari t-tabel (t-tabel signifikansi 5\%=1,68), dan koefisien jalur memiliki nilai positif.

Hal penelitian menunjukkan bahwa pembiayaan sistem bagi hasil memiliki pengaruh yang signifikan dengan pola hubungan yang positif terhadap kinerja usaha tani tebu. Hasil ini dapat menjelaskan bahwa semakin baik sistem bagi hasil yang diterima oleh usaha tani tebu di Bondowoso akan mendorong peningkatan terhadap kinerja usaha tani tebu.

\section{Pengarub Asset Usaha Tani Tebu Terhadap Inovasi Bisnis}

Tabel 7, menunjukkan koefisien jalur dalam model yang digunakan. Penelitian ini menghasilkan temuan bahwa variabel Asset usaha tani tebu berpengaruh secara signifikan terhadap Inovasi Bisnis. Hal ini dilihat dari nilai t-hitung 2,292161 lebih besar dari ttabel (t-tabel signifikansi 5\%=1,68), dan koefisien jalur memiliki nilai positif.

Asset adalah semua sumber daya yang dikuasai oleh perusahaan dalam rangka menghasilkan keuntungan. Salah satu bentuk asset yang dimiliki oleh petani adalah kas atau uang. Dengan uang yang dimiliki, petani dapat mencari teknologi yang dapat meningkatkan baik secara kualitas maupun kuantitas hasil usaha tebu. Asset yang dimiliki juga dapat berguna untuk melakukan berbagai pengembangan dan pembaharuan dalam penerapan teknologi terbaru pertanian tebu. Sehingga terdapat hubungan antara asset usaha tani dengan inovasi bisnis. 
Pengarub Asset Usaha Tani Tebu Terhadap Kinerja Usaha Tani Tebu

Tabel 7, menunjukkan koefisien jalur dalam model yang digunakan. Penelitian ini menghasilkan temuan bahwa variabel Asset usaha tani tebu berpengaruh secara signifikan terhadap kinerja usaha tani tebu. Hal ini dilihat dari nilai t-hitung 4,468411 lebih besar dari t-tabel (t-tabel signifikansi 5\%=1,68), dan koefisien jalur memiliki nilai positif.

Perencanaan dan pengelolaan asset sangat penting untuk mengembangkan suatu usaha. Control yang baik dan penggunaan yang terencana atas asset akan mempengaruhi berkembang tidaknya asset yang dimiliki oleh perusahaan. Petani tebu di Bondowoso selalu melakukan kerjasama yang baik dengan pabrik tebu maupun penyuluh pertanian. Penggunaan dana untuk pembelian bibit yang unggul dan biaya pengolahan agar menghasilkan tebu kualitas unggul ternyata dapat diterapkan dengan baik. Hal ini kemudian menghasilkan peningkatan keuntungan yang signifikan di pihak petani tebu bondowoso. Ini menunjukkan bahwa asset usaha tani tebu memiliki hubungan dengan kinerja usaha tani tebu.

\section{Pengarub Inovasi Bisnis Terhadap Pertumbuhan Pelanggan}

Tabel 7, menunjukkan koefisien jalur dalam model yang digunakan. Penelitian ini menghasilkan temuan bahwa variabel Inovasi bisnis berpengaruh secara signifikan terhadap pertumbuhan Pelanggan. Hal ini dilihat dari nilai t-hitung 2,157487 lebih besar dari t-tabel (t-tabel signifikansi 5\%=1,68), dan koefisien jalur memiliki nilai positif.

Petani tebu bondowoso selalu menggunakan bibit unggul dalam setiap melakukan kegiatan penanaman. Bibit ini dapat berasal dari pemerintah maupun dari pabrik tebu. Petani juga secara rutin mendapatkan penyuluhan dari dinas terkait. Hal ini menumbuhkan inovasi dalam bisnis tebu di kalangan petani tebu bondowoso. Dari hasil survey, permintaan produksi tebu meningkat dari tahun ke tahun seiring dengan inovasi yang dilakukan seiring dengan meningkatnya kapasitas produksi. Ini menunjukkan bahwa pelanggan produk tebu meningkat setiap tahunnya. Dapat disimpulkan bahwa inovasi bisnis berpengaruh terhadap pertumbuhan pelanggan. 


\section{Pengaruh Inovasi Bisnis Terhadap Kinerja Usaha Tani Tebu}

Berdasarkan Tabel 7, menunjukkan koefisien jalur dalam model yang digunakan. Penelitian ini menghasilkan temuan bahwa variabel Inovasi bisnis berpengaruh secara signifikan terhadap kinerja usaha tani tebu. Hal ini dilihat dari nilai t-hitung 3,200987 lebih besar dari t-tabel (t-tabel signifikansi 5\%=1,68), dan koefisien jalur memiliki nilai positif.

Penggunaan bibit unggul dan teknologi yang terbaru dalam proses penanaman tebu selalu dipraktekkan oleh petani tebu. Dari hasil survey, petani tebu memiliki kelompok tani yang secara berkala mendapatkan penyuluhan dari departemen pertanian. Dalam kelompok tani didskusikan mengenai kesulitan dan hambatan yang dialami oleh para petani tebu. Tidak hanya itu, pabrik tebu juga memberikan informasi terbaru dalam teknik penanaman dan bibit unggul. Para stake holder, dalam hal ini depertemen pertanian dan pabrik tebu, bahkan memberikan bantuan baik berupa pinjaman maupun bantuan bibit untuk kemajuan pertanian tebu. Hasilnya, inovasi yang dilakukan dalam penanaman tebu mampu meningkatkan kinerja usaha tani.

Pengarub Pertumbuhan Pelanggan Terhadap Kinerja Usaha Tani Tebu

Tabel 7, menunjukkan koefisien jalur dalam model yang digunakan. Penelitian ini menghasilkan temuan bahwa variabel Pertumbuhan Pelanggan berpengaruh secara signifikan terhadap kinerja usaha tani tebu. Hal ini dilihat dari nilai t-hitung 3,216714 lebih besar dari t-tabel (t-tabel signifikansi 5\%=1,68), dan koefisien jalur memiliki nilai positif.

Permintaan yang tinggi dan bahkan tidak terbatas untuk hasil tanaman tebu, memicu pemerintah untuk terus mendorong pertumbuhan hasil tanaman tebu dan membeli semua hasil pertanian tebu.. Pemerintah sampai saat ini bahkan masih melakukan impor gula untuk memenuhi kebutuhan gula nasional. Ini dipahami oleh petani untuk terus meningkatkan hasil pertanian. Usaha yang dilakukan antara lain dengan membentuk kelompok tani. Dalam kelompok tani tidak hanya mengatur masalah penggunaan 
teknologi, tetapi juga terkait dengan biaya tani dan harga jual hasil pertanian. Khusus harga jual tebu, kekuatan kelompok tani sampai saat ini berpengaruh besar terhadap kebijakan nasional mengenai harga jual hasil pertanian tebu. Berdasar hasil survey, umumnya petani memperoleh hasil yang tinggi dari penanaman tebu. Bahkan keuntungan yang diperoleh sampai 1000\%. Ini menunjukkan bahwa pertumbuhan pelanggan turut meningkatkan kinerja usaha tani.

\section{Kesimpulan}

Berdasarkan hasil analisis dan pembahasan yang telah diuraikan sebelumnya, maka kesimpulan di dalam penelitian ini adalah: 1) Pembiayaan berpengaruh signifikan terhadap inovasi bisnis. Hasil penelitian menunjukkan bahwa pembiayaan sistem bagi hasil memiliki pengaruh yang signifikan dengan pola hubungan yang positif terhadap inovasi bisnis. Hasil ini dapat menjelaskan bahwa semakin baik sistem bagi hasil yang diterima oleh usaha tani tebu di Bondowoso akan mendorong peningkatan terhadap inovasi bisnis. 2) Pembiayaan berpengaruh signifikan terhadap kinerja usaha tani tebu. Hasil penelitian menunjukkan bahwa pembiayaan sistem bagi hasil memiliki pengaruh yang signifikan dengan pola hubungan yang positif terhadap kinerja usaha tani tebu. Hasil ini dapat menjelaskan bahwa semakin baik sistem bagi hasil yang diterima oleh usaha tani tebu di Bondowoso akan mendorong peningkatan terhadap kinerja usaha tani tebu. 3) Asset usaha tani tebu berpengaruh signifikan terhadap inovasi bisnis. Asset adalah semua sumber daya yang dikuasai oleh perusahaan dalam rangka menghasilkan keuntungan. Salah satu bentuk asset yang dimiliki oleh petani adalah kas atau uang. Dengan uang yang dimiliki, petani dapat mencari teknologi yang dapat meningkatkan baik secara kualitas maupun kuantitas hasil usaha tebu, serta dapat digunakan untuk pengembangan dan pembaharuan dalam penerapan teknologi terbaru pertanian tebu. Sehingga terdapat hubungan antara asset usaha tani dengan inovasi bisnis. 4) Asset usaha tani tebu berpengaruh signifikan terhadap kinerja usaha tani tebu. Perencanaan dan pengelolaan asset sangat penting untuk mengembangkan suatu usaha. Penggunaan dana untuk pembelian bibit yang unggul 
dan biaya pengolahan agar menghasilkan tebu kualitas unggul ternyata dapat diterapkan dengan baik. Hal ini kemudian menghasilkan peningkatan keuntungan yang signifikan di pihak petani tebu bondowoso. Ini menunjukkan bahwa asset usaha tani tebu memiliki hubungan dengan kinerja usaha tani tebu. 5) Inovasi bisnis berpengaruh signifikan terhadap pertumbuhan pelanggan. Petani tebu Bondowoso selalu menggunakan bibit unggul dalam setiap melakukan kegiatan penanaman. Bibit ini dapat berasal dari pemerintah maupun dari pabrik tebu. Petani juga secara rutin mendapatkan penyuluhan dari dinas terkait. Hal ini menumbuhkan inovasi dalam bisnis tebu di kalangan petani tebu Bondowoso. Dari hasil survey, permintaan produksi tebu meningkat dari tahun ke tahun seiring dengan inovasi yang dilakukan seiring dengan meningkatnya kapasitas produksi. Ini menunjukkan bahwa pelanggan produk tebu meningkat setiap tahunnya. Dapat disimpulkan bahwa inovasi bisnis berpengaruh terhadap pertumbuhan pelanggan. 6) Inovasi bisnis berpengaruh signifikan terhadap kinerja usaha tani tebu. Penggunaan bibit unggul dan teknologi yang terbaru dalam proses penanaman tebu selalu dipraktekkan oleh petani tebu. Para stake holder, dalam hal ini depertemen pertanian dan pabrik tebu, memberikan bantuan baik berupa pinjaman maupun bantuan bibit untuk kemajuan pertanian tebu. Hasilnya, inovasi yang dilakukan dalam penanaman tebu mampu meningkatkan kinerja usaha tani. 7) Pertumbuhan pelanggan berpengaruh signifikan terhadap kinerja usaha tani tebu. Permintaan yang tinggi dan bahkan tidak terbatas untuk hasil tanaman tebu, memicu pemerintah untuk terus mendorong pertumbuhan hasil tanaman tebu dan membeli semua hasil pertanian tebu.Usaha yang dilakukan antara lain dengan membentuk kelompok tani. Dalam kelompok tani tidak hanya mengatur masalah penggunaan teknologi, tetapi juga terkait dengan biaya tani dan harga jual hasil pertanian. Khusus harga jual tebu, kekuatan kelompok tani sampai saat ini berpengaruh besar terhadap kebijakan nasional mengenai harga jual hasil pertanian tebu. Berdasar hasil survey, umumnya petani memperoleh hasil yang tinggi dari penanaman tebu. Bahkan keuntungan yang diperoleh sampai 1000\%. Ini menunjukkan bahwa pertumbuhan pelanggan turut meningkatkan kinerja usaha tani. 


\section{Daftar Pustaka}

Cooper, J.R.1998. A Multidimensional Approach to the Adoption of Innovation. Management Decision, 36(8): 493-502.

Damanpour, F. 1991. Organizational Innovation: A Meta Analysis of Effect of Determinants and Moderators. Academy of Management Jour-nal, 34(3): 555-590.

John A. Pearce II, Richard B. Robinson, Jr. 2013. Manajemen Strategis Formulasi, Implementasi, dan Pengendalian. (terjemahan). Buku 1 Edisi 12. Salemba Jakarta

Hurley, R. \& Hult, G.T. 1998. Innovation, Market Orientation and Organizational Learning: An Integration and Empirical Exmination. Journal of Marketing, 62(3): 42-54.

Kusumo, Agung Raharjo Wibowo. 2006. Analisis Faktor-Faktor Yang Mempengaruhi Inovasi Produk Untuk Meningkatkan Keunggulan Bersaing dan Kinerja Pemasaran di kabupaten Pekalongan

Quinn, J.B., Baruch, J. \& Zien, K. A. 1996. Software-based innovation. Sloan Management Review, 37(4): 11-24.

Republik Indonesia. 2008. Undang-Undang No. 20/2008 Tentang Usaha mikro, Kecil dan Menengah. 